\title{
Impact of Demographic Traits and Personality Traits of Investors on Their Risk-Bearing Capacity: A Study with Special Reference to Investors of Kerala
}

\author{
Athira K \\ $\mathrm{PhD}$ Research Scholar \\ Department of Commerce \\ Sree Narayana College \\ Kannur University \\ Kerala, India \\ E-mail: athiraksanilkumar@gmail.com \\ Mohamed Kutty Kakkakunnan $P h D$ \\ Principal \\ NAM College, Kallikkandy \\ Kannur University \\ Kerala, India \\ E-mail: mohamedkutty@namcollege.ac.in
}

Received: July 29, 2020

Accepted: August 09, 2020

Online Published: August 29, 2020

doi: I0.4628I/ijfb.v4i2.737

URL: https://doi.org/I0.4628I/ijfb.v4i2.737

\begin{abstract}
Investment decisions form a major part of every individual's life. Behavioral finance which puts forward a new dimension in the field of finance recognizes that investment decisions are made after considering numerous psychological, economical and social factors. One of the important criteria considered while making any such decision is the risk. It includes uncertainties associated with the investment opportunity as well as the investors' risk-bearing capacity. Investors' risk-bearing capacity is in turn determined by numerous other aspects. An effort is made here to determine whether the risk-bearing capacities of investors are influenced by the demographic factors and personality traits. I20 investors of Kerala State were selected as the sample for this purpose. Analytical results indicated that the risk-bearing capacity is dependent on gender, occupation, and monthly income of the investors. Further, it was noticed that those who have low neuroticism scores and high scores in agreeableness, extraversion, and conscientiousness took higher risks compared to others. This indicated that neuroticism trait was found to have a negative correlation with risk-bearing capacity whereas; agreeableness, extraversion, and conscientiousness were found to have a positive relation. The study concluded that factors like demography and personality have a strong influence on an investor's risk-bearing capacity.
\end{abstract}

Keywords: Demographic Traits, Investment Pattern, Personality Traits, Risk-Bearing Capacity.

\section{Introduction}

In everyday life, people take a variety of decisions considering their pros and cons. All these decisions are based on their understanding level, age, moral values they hold, their personality, the urgency of the situation, etc. The basic idea behind every decision is what will its consequences be, whether negative or positive. Similarly, when one makes an investment decision, they consider what returns they will get from investing in that particular product and what will be the risk they would be taking while investing. Many factors influence investors' decisions. Risk is a major component of investment, understanding the nature of risk, and the capacity to take risks becomes a very essential part of investors' decisions. Risk is perceived as "an exposure to a proposition of which one is uncertain" (Holton, 2004). The risk associated with an asset includes the features of the asset, maturity period, amount to invest, mode of investing, and many more. Hence, at the time of decision making regarding any investment opportunity, risk accompanying that product becomes a major constituent of that decision (Dhiman \& Raheja, 2018).

Though traditional finance theories assume investors' decisions are based on rationality, in actual practice, this is not the case. Emotions, personality, personal beliefs, and many other factors influence a person's decision. Durand, Newby, Peggs, and Siekierka (2013) remarked that decision regarding formation of a portfolio is made by giving more importance to the risk involved than the price of the securities and returns that will be obtained from them. Another aspect considered by investors is the availability of information regarding the securities. These aspects are explained better by the advent of behavioral finance, which describes why and how people make investment choices. The investment decisions of a person are 
determined by numerous socio-economic and behavioral factors. Understanding these determinants becomes a part of behavioral finance (Dhiman \& Raheja, 2018).

Whenever a person invests, it will be based on an investment goal that he wants to achieve. The amount of risk that a person is willing to take for the accomplishment of his goal becomes his risk-bearing capacity. The maximum amount of uncertainty that an investor can bear while investing is referred to as investor's risk tolerance level and successful investment decisions are attained by those who have a comprehensive understanding of financial risk tolerance (Gondaliya \& Dhinaiya, 2016). A huge part of the investment decisions is based on the behavior of investors. When investors fail to include or ignore this aspect, it can have detrimental consequences on the performance of their investment products in terms of desirable returns expected from them, especially in the long run. Risk being a vital component of decision making and investments, understanding the factors that can have an impact on risk-bearing capacity becomes essential.

The demographic profile of an investor includes factors like age, gender, educational qualifications, occupation, income, etc. The personality of an individual comprises of their intellectual level, moral values, thought processes, feelings, temperament, skills, etc. and plays a predominant role in their life. Personalities are distinctive and are a combination of the inherent characteristics and behavior of an individual. Everyone behaves differently in different situations. Durand, Newby, Tant, and Trepongkaruna (2013) stated that personality is a fundamental component of almost all decisions, and understating investors' personalities become the principal requirement for developing a comprehensive finance theory. Being an integral component of decision making and behavior of an individual, personality may have a crucial role to play in their risk acceptance behavior. Hence, it becomes essential to understand the influence of demographic traits and personality traits on investors' risk-bearing capacity and to see how it ultimately affects their investment pattern. Understanding these aspects can enlighten the investors by helping them in choosing the best investment product and services, and in adopting the best investment strategy to attain their investment objectives. It will also be beneficial for the financial advisors in guiding their clients by gaining a better understanding of their clients' behavior.

The present study is carried out among the individual investors in the state of Kerala in order to comprehend the impact of various demographic variables on the risk-bearing capacity of the investors and to examine how the differences in the personality of individuals affect their risk-bearing capacity while making investment decisions. The focus of this work is on figuring out whether demographic traits and personality traits are related to the risk-bearing capacity of investors.

\section{Review of Literature}

Gondaliya and Dhinaiya (2016) observed a notable relationship between risk tolerance and the demographic profile of investors. They pointed out that a substantial relation existed between factors like marital status, age, education, occupation, and annual income on the degree of risk tolerance of an investor. High-risk tolerance was found in investors who are male and single and an increase in income level resulted in increasing their risk-taking capacity to an even higher level (Thanki \& Baser, 2019). When an uncertain situation originates the emotional reaction of men and women to that situation tends to be different. Likewise, men are usually more confident and challenge seeking than women. These differences in emotional reaction, confidence, and challenge seeking behavior of men make them more tolerant to risk than women (Croson \& Gneezy, 2009).

Alwahaibi (2019) mentioned in his study that an increase in the level of education and monthly income has a positive relationship with their risk-tolerance level. Further, he stated that investment decisions and risk tolerance are interconnected and demographic elements play a vital role in defining this linkage. Investors with a relatively large amount of income, education, and financial knowledge are comparatively more tolerant to risk than others (Grable, 2000). Dwyer, Gilkeson, and List (2002) observed that when investors were provided with financial education in addition to general education, they tend to take more risk than before. They remarked that generally women are described as risk-averse but once they are imparted with financial education, their risk aversion is reduced considerably. They suggested that by providing financial education risk aversion of investors can be reduced. Outreville (2015) also supports the view that higher education attained by people contributes to lowering their risk avoidance and the results of the study pointed out that more skilled and well-educated people are, greater the risk they take. Asano and Tachibanaki (1994) conducted a study on Japanese households and observed that households tend to diversify their portfolio when the total assets held by them increases. Which, in turn, indicated the lowering of aversion towards risk by larger asset holders?

Gupta and Agarwal (2018) in their paper focused on addressing the association between portfolio investors' personality and biases displayed by them. It became evident from the results that extraversion, openness, and neuroticism have a positive correlation with hindsight bias, overconfidence bias, and randomness bias respectively. A negative correlation was observed between conscientiousness and randomness bias, agreeableness and randomness bias, and openness trait and availability bias. They strongly opine that understanding one's personality and biases will be beneficial to investors, as it enables them to make better decisions.

Dhiman and Raheja (2018) examined whether personality traits and emotional intelligence of a person have any influence on their risk tolerance. The findings showed investors with high scores in agreeableness, extraversion, and openness prefer to adopt more risks. Analysis based on emotional intelligence indicated that investors who are good at handling emotions, motivated, and self-aware about their strengths and weaknesses takes more risk and better investment decisions compared to other people. They concluded by stating that the personality and emotional intelligence of an investor are vital determinants of their risk tolerance level, and among the two, emotional intelligence is the most influential factor. 
Dickason and Ferreira (2018) categorized investors depending upon their risk tolerance level and personality. They carried out a study to identify which investment biases are associated with which category of investors, to assess how they choose investment options. They pointed out that conservative and low risk-tolerant investors displayed mental accounting and loss aversion bias indicating that they continue to stick on to their assets even when they are incurring a loss. Investors who were growth-oriented and who took moderate risk were prone to overconfidence, availability, regret aversion, and anchoring bias denoting that they relied more on past information rather than using present information. Aggressive investors with high tolerance towards risk had self-control bias and tempted to make impulsive decisions without considering the consequences of the decision. This kind of investor profiling by Dickason and Ferreira (2018) can help investment companies in determining how investment decisions are taken and create investment products suitable for each category of investors.

Mayfield, Perdue, and Wooten (2008) outlined the short-term and long-term investment intentions of investors by focusing on their personality. They found that extravert individuals made investments in short term instruments and those who were more experimental preferred long-term assets and took more risk compared to others.

Thomas and Rajendran (2012) stated that investors' preferences and choices made by them are certainly influenced by their personality. They pointed out that, getting an understanding of one's personality can help investors in making the right choices. Isidore and Christie (2017) remarked that identifying the investors' personality would be beneficial to the financial advisors for customizing the financial products to be offered and to give the investors proper assistance while they invest.

\section{Objectives of the Research}

- To understand the demographic profile of the individual investors of Kerala.

- To detect the investment pattern of the individual investors of Kerala.

- To determine the risk-bearing capacity of the individual investors of Kerala.

- To recognize the personality traits of the individual investors of Kerala.

- To evaluate the impact of the demographic traits of the individual investors of Kerala on their risk-bearing capacity.

- To analyze the influence of the personality traits on the risk-bearing capacity of the individual investors of Kerala.

\section{Hypotheses}

- $\mathrm{H}_{\mathrm{I}}$ : Risk-bearing capacity of an investor is dependent on their demographic characteristics.

- $\mathrm{H}_{2}$ : Risk-bearing capacity of an investor is dependent on their personality traits.

\section{Research Methodology}

The study follows a descriptive and analytical research design. The area under research is the state of Kerala, which is a South Indian state. The population for the study is all individual investors of Kerala. A sample of I20 individual investors of Kerala was selected for the study through the convenience sampling method. Primary data acquired through a questionnaire (see Appendix) categorized into four parts, supported the study. The first part comprised of questions about the demographic information of the investors. The second section consisted of questions related to the investment pattern of investors. The third part is related to risk-bearing capacity, and the final part dealt with statements related to the personality traits exhibited by them. Different books and journals provided secondary data for the research. The statistical instruments used for the study are percentage analysis, mean values, chi-square test, and correlation. The analysis is performed using SPSS (22).

6. Results and Discussion

6.I Demographic Profile

Table I. Demographic profile of the respondents

\begin{tabular}{|c|c|c|c|}
\hline & & Frequency & Percent \\
\hline \multirow[t]{7}{*}{ Age } & Up to 25 & $\mathrm{I} 2$ & 10.0 \\
\hline & $26-30$ & 26 & 21.7 \\
\hline & $31-40$ & 40 & 33.3 \\
\hline & $4 \mathrm{I}-50$ & I9 & 15.8 \\
\hline & $5 I-60$ & I6 & I3.3 \\
\hline & $6 \mathrm{I}$ and above & 7 & 5.8 \\
\hline & Total & 120 & 100.0 \\
\hline \multirow[t]{2}{*}{ Gender } & Female & 54 & 45.0 \\
\hline & Male & 66 & 55.0 \\
\hline
\end{tabular}




\begin{tabular}{|c|c|c|c|}
\hline & Total & 120 & 100.0 \\
\hline \multirow[t]{5}{*}{ Marital Status } & Single & 33 & 27.5 \\
\hline & Married & 84 & 70.0 \\
\hline & Divorced & 2 & 1.7 \\
\hline & Widowed & $\mathrm{I}$ & .8 \\
\hline & Total & 120 & 100.0 \\
\hline \multirow[t]{6}{*}{ Educational Qualification } & High School & 3 & 2.5 \\
\hline & Senior Secondary & $\mathrm{IO}$ & 8.3 \\
\hline & Graduation & 50 & $4 \mathrm{I} .7$ \\
\hline & Post Graduation & 53 & 44.2 \\
\hline & Others & 4 & 3.3 \\
\hline & Total & 120 & 100.0 \\
\hline \multirow[t]{7}{*}{ Occupation } & Salaried & 48 & 40.0 \\
\hline & Self Employed & 16 & 13.3 \\
\hline & Business & 17 & $\mathrm{I} 4.2$ \\
\hline & Professional & 25 & 20.8 \\
\hline & Retired & 10 & 8.3 \\
\hline & Other & 4 & 3.3 \\
\hline & Total & 120 & 100.0 \\
\hline \multirow[t]{6}{*}{ Monthly Income } & Up To 25,000 & 27 & 22.5 \\
\hline & $25,001-50,000$ & 45 & 37.5 \\
\hline & $50,001-75,000$ & 27 & 22.5 \\
\hline & $75,001-1,00,000$ & 16 & I3.3 \\
\hline & Above I00,00I & 5 & 4.2 \\
\hline & Total & $\mathrm{I} 20$ & 100.0 \\
\hline
\end{tabular}

Table I presents the demographic profile distribution of 120 individual investors of Kerala. As seen in the table, $10 \%$ of the respondents were of the age up to $25,21.7 \%$ of them were of the age $26-30,33.3 \%$ of them were of the age $3 \mathrm{I}-40, \mathrm{I} 5.8 \%$ of them were of the age $4 \mathrm{I}-50, \mathrm{I} 3.3 \%$ of them were of the age $5 \mathrm{I}-60$ and $5.8 \%$ of them were above $6 \mathrm{I}$ years old. Regarding the respondents' gender, $45 \%$ of them were female and $55 \%$ were male. The majority of the respondents were married $(70 \%)$ and $27.5 \%$ were single, $1.7 \%$ were divorced, and $0.8 \%$ were widowed. In respect to educational background, most of the participants in the survey were post-graduates (44.2\%) and graduates (4I.7\%). According to occupational status, $40 \%$ were salaried, I3.3\% were self-employed, I4.2\% did business, $20.8 \%$ were professionals, $8.3 \%$ were retired, and 3.3\% did other occupations. Regarding the monthly income of the investors, $22.5 \%$ earned up to Rs. 25000, 37.5\% of them earned between Rs. 2500I - Rs. 50000, 22.5\% earned Rs. 50,00I - Rs. 75,000, I3.3\% earned Rs. $75,00 I$ - Rs. I,00,000, and $4.2 \%$ of them earned above Rs. I00,00I in a month.

\subsection{Investment Pattern}

Table 2. Investments per month made by the respondents

\begin{tabular}{lll}
\hline Investments per month & Frequency & Percent \\
\hline Up to 2,500 & $3 \mathrm{I}$ & 25.8 \\
\hline $2,50 \mathrm{I}-5,000$ & 22 & $\mathrm{I} 8.3$ \\
\hline $5,00 \mathrm{I}-7,500$ & 20 & $\mathrm{I} 6.7$ \\
\hline $7,50 \mathrm{I}-\mathrm{I} 0,000$ & $\mathrm{I}$ & $\mathrm{I} 5.8$ \\
\hline Above I0,00I & 28 & 23.3 \\
\hline Total & $\mathrm{I} 20$ & $\mathrm{I}$ \\
\hline
\end{tabular}

Investments made by investors in a month are denoted in Table 2 . The results indicate that $25.8 \%$ of the investors invested up to Rs. 2500, I8.3\% invested between Rs. 250I - Rs. 5000, I6.7\% invested between Rs. 5,00I - Rs. 7,500, I5.8\% invested between Rs. 750 I - Rs. I0000 and 23.3\% invested above Rs. I000I in a month. 
Table 3. Frequency of making investments

\begin{tabular}{lll}
\hline Frequency of making investments & Frequency & Percent \\
\hline Once in a month & 64 & 53.3 \\
\hline Once in 3 months & 32 & 26.7 \\
\hline Once in 6 months & 3 & 2.5 \\
\hline Once in a year & 7 & 5.8 \\
\hline Combination of all of the above & $\mathrm{I} 4$ & $\mathrm{I} 1.7$ \\
\hline Total & $\mathrm{I} 20$ & $\mathrm{I00.0}$ \\
\hline
\end{tabular}

Table 3 denotes how often investors make their investments. It can be seen that the majority of them invested once in a month (53.3\%), followed by once in 3 months (26.7\%). Only a few made investments once a year (5.8\%), and II.7\% of the respondents invested in a combined way.

Table 4. Objectives of making investment

\begin{tabular}{lcccccc}
\hline Objectives of making investment & \multicolumn{7}{c}{ Responses } \\
\cline { 2 - 7 } & Yes & Percent & No & Percent & Total & Percent \\
\hline Higher returns & 77 & $64.2 \%$ & 43 & $35.8 \%$ & $\mathrm{I} 20$ & $\mathrm{I} 00 \%$ \\
\hline Tax benefits & 68 & $56.7 \%$ & 52 & $43.3 \%$ & $\mathrm{I} 20$ & $\mathrm{I} 00 \%$ \\
\hline Safety of money & 66 & $55.0 \%$ & 54 & $45.0 \%$ & $\mathrm{I} 20$ & $\mathrm{I} 00 \%$ \\
\hline Financial independence & 62 & $51.7 \%$ & 58 & $48.3 \%$ & $\mathrm{I} 20$ & $\mathrm{I} \% 0 \%$ \\
\hline Retirement purpose & 54 & $45.0 \%$ & 66 & $55.0 \%$ & $\mathrm{I} 20$ & $\mathrm{I} \% 0 \%$ \\
\hline Children's education and marriage & 32 & $26.7 \%$ & 88 & $73.3 \%$ & $\mathrm{I} 20$ & $100 \%$ \\
\hline Stable income & 36 & $30.0 \%$ & 84 & $70.0 \%$ & $\mathrm{I} 20$ & $100 \%$ \\
\hline Other Objectives & 0 & $0 \%$ & $\mathrm{I} 20$ & $\mathrm{I} 00 \%$ & $\mathrm{I} 20$ & $\mathrm{I} 00 \%$ \\
\hline
\end{tabular}

Objectives of investors while making investments are shown in table 4. From the results, it can be understood that the main objectives behind making investments in various financial products were for obtaining higher returns $(64.2 \%)$, tax benefits $(56.7 \%)$, the safety of money (55.0\%), financial independence (51.7\%), and for retirement purpose $(45.0 \%)$.

Table 5. Period of investment preferred

\begin{tabular}{lll}
\hline Period of investment preferred & Frequency & Percent \\
\hline 0-I year & 26 & 21.7 \\
\hline I-3 years & 45 & 37.5 \\
\hline 3-5 years & 20 & 16.7 \\
\hline Above 5 years & 29 & 24.2 \\
\hline Total & 120 & 100.0 \\
\hline
\end{tabular}

Table 5 illustrates the period for which investors wish to hold their investment. It can be seen that the majority of them wish to hold their investments for a period of I-3years (37.5\%) indicating their keenness to have short-term assets. The table also shows that $21.7 \%$ of them hold their investment for less than a year, $16.7 \%$ them retain their assets for 3 to 5 years, and $24.2 \%$ of them hold their investments for a longer period.

Table 6. Current investments

\begin{tabular}{lllllll}
\hline Current Investments & \multicolumn{7}{c}{ Responses } \\
\cline { 2 - 7 } & Yes & Percent & No & Percent & Total & Percent \\
\hline Bank deposit & 99 & $82.5 \%$ & $2 \mathrm{I}$ & $\mathrm{I} 7.5 \%$ & $\mathrm{I} 20$ & $\mathrm{I} 00 \%$ \\
\hline Postal savings & 38 & $31.7 \%$ & 82 & $68.3 \%$ & $\mathrm{I} 20$ & $\mathrm{I} 00 \%$ \\
\hline Provident fund & $5 \mathrm{I}$ & $42.5 \%$ & 69 & $57.5 \%$ & $\mathrm{I} 20$ & $\mathrm{I} 00 \%$ \\
\hline SIP & 39 & $32.5 \%$ & $8 \mathrm{I}$ & $67.5 \%$ & $\mathrm{I} 20$ & $\mathrm{I} 00 \%$ \\
\hline
\end{tabular}




\begin{tabular}{lllllll}
\hline Insurance & 78 & $65.0 \%$ & 42 & $35.0 \%$ & $\mathrm{I} 20$ & $\mathrm{I} 00 \%$ \\
\hline Gold and silver & 46 & $38.3 \%$ & 74 & $61.7 \%$ & $\mathrm{I} 20$ & $\mathrm{I} 00 \%$ \\
\hline Real estate & $\mathrm{I} 7$ & $\mathrm{I} 4.2 \%$ & $\mathrm{I} 03$ & $85.8 \%$ & $\mathrm{I} 20$ & $\mathrm{I00} \%$ \\
\hline Chit funds & 34 & $28.3 \%$ & 86 & $71.7 \%$ & $\mathrm{I} 20$ & $\mathrm{I} 00 \%$ \\
\hline Mutual funds & 48 & $40.0 \%$ & 72 & $60.0 \%$ & $\mathrm{I} 20$ & $\mathrm{I} 00 \%$ \\
\hline Shares & 32 & $26.7 \%$ & 88 & $73.3 \%$ & $\mathrm{I} 20$ & $\mathrm{I} \% 0 \%$ \\
\hline Others & 2 & $\mathrm{I} .7 \%$ & $\mathrm{I} 18$ & $98.3 \%$ & $\mathrm{I} 20$ & $\mathrm{I} \% 00$ \\
\hline
\end{tabular}

Respondents' current investment holdings are shown in table 6. The table illustrates bank deposits (82.5\%) score the highest in the current investments of these investors. Insurance (65.0\%), provident fund (42.5\%), mutual funds (40\%), and gold and silver $(38.3 \%)$ form the other major portion of investors' current portfolio. Only a few had their investments made in shares $(26.7 \%)$ and real estate (I4.2\%).

Table 7. Investment preference

\begin{tabular}{|c|c|c|c|c|c|c|}
\hline \multirow[t]{2}{*}{ Investment product } & \multicolumn{2}{|c|}{ Rank I } & \multicolumn{2}{|c|}{ Rank 2} & \multicolumn{2}{|c|}{ Rank 3} \\
\hline & Frequency & Percent & Frequency & Percent & Frequency & Percent \\
\hline Bank deposit & 63 & 52.5 & 9 & 7.5 & 9 & 7.5 \\
\hline Postal savings & 3 & 2.5 & 12 & 10.0 & 5 & 4.2 \\
\hline Provident fund & $\mathrm{I} 2$ & 10.0 & 5 & 4.2 & 8 & 6.7 \\
\hline Gold and silver & 2 & 1.7 & 7 & 5.8 & 34 & 28.3 \\
\hline Insurance & 3 & 2.5 & 53 & 44.2 & 18 & I5.0 \\
\hline Real estate & 2 & $\mathrm{I} .7$ & 5 & 4.2 & 5 & 4.2 \\
\hline Shares & 17 & $\mathrm{I} 4.2$ & 7 & 5.8 & 5 & 4.2 \\
\hline Mutual funds & 10 & 8.3 & $\mathrm{I3}$ & 10.8 & 18 & 15.0 \\
\hline SIP & 5 & 4.2 & 5 & 4.2 & 10 & 8.3 \\
\hline Chit funds & 3 & 2.5 & 4 & 3.3 & 8 & 6.7 \\
\hline Total & $\mathrm{I} 20$ & 100.0 & $\mathrm{I} 20$ & 100.0 & $\mathrm{I} 20$ & 100.0 \\
\hline
\end{tabular}

Table 7 exhibits the respondents' preference towards the selected investment avenues and was asked to rank the same in their order of preference. The first rank for the most preferred product was secured by the bank deposit (52.5\%). Insurance (44.2\%) was given the position of the second most preferred product, followed by gold and silver $(28.3 \%)$.

Table 8. Source of information

\begin{tabular}{|c|c|c|c|c|c|c|}
\hline \multirow[t]{2}{*}{ Source of information } & \multicolumn{6}{|c|}{ Responses } \\
\hline & Yes & Percent & No & Percent & Total & Percent \\
\hline Self-analysis & 89 & $74.2 \%$ & $3 I$ & $25.8 \%$ & 120 & $100 \%$ \\
\hline Spouse & 23 & $19.2 \%$ & 97 & $80.8 \%$ & $\mathrm{I} 20$ & $100 \%$ \\
\hline Family & 49 & $40.8 \%$ & $7 \mathrm{I}$ & $59.2 \%$ & 120 & $100 \%$ \\
\hline Friends & 60 & $50.0 \%$ & 60 & $50.0 \%$ & 120 & $100 \%$ \\
\hline Colleagues & 38 & $31.7 \%$ & 82 & $68.3 \%$ & 120 & $100 \%$ \\
\hline Financial Institutions & 34 & $28.3 \%$ & 86 & $71.7 \%$ & 120 & $100 \%$ \\
\hline Financial websites & 34 & $28.3 \%$ & 86 & $71.7 \%$ & 120 & $100 \%$ \\
\hline Advertisements & 30 & $25.0 \%$ & 90 & $75.0 \%$ & 120 & $100 \%$ \\
\hline Others & 3 & $2.5 \%$ & II7 & $97.5 \%$ & 120 & $100 \%$ \\
\hline
\end{tabular}

Table 8 denotes the sources from where the investors gather investment information. The result shows that selfanalysis $(74.2 \%)$ was the major source of information, accompanied by friends (50.0\%), and family (40.8\%). Sources like information from financial institutions (28.3\%), financial websites $(28.3 \%)$, and advertisements $(25.0 \%)$ were also relied upon by the investors. 
Table 9. Investment experience

\begin{tabular}{lll}
\hline Investment experience & Frequency & Percent \\
\hline $0-$ I year & 28 & 23.3 \\
\hline $2-5$ years & 43 & 35.8 \\
\hline $5-10$ years & $2 \mathrm{I}$ & 17.5 \\
\hline Above I0 years & 28 & 23.3 \\
\hline Total & $\mathrm{I} 20$ & 100.0 \\
\hline
\end{tabular}

Table 9 reports that $23.3 \%$ of the respondents had an investment experience of less than a year, $35.8 \%$ of them had an investment experience of two to five years, $17.5 \%$ of them had an experience of five to ten years, and $23.3 \%$ of them had investment experience for more than ten years.

\subsection{Risk-Bearing Capacity}

Table IO. Risk-bearing capacity

\begin{tabular}{lll}
\hline Risk bearing capacity & Frequency & Percent \\
\hline No risk & 8 & 6.7 \\
\hline Low risk & 39 & 32.5 \\
\hline Moderate risk & 40 & 33.3 \\
\hline High Risk & 33 & 27.5 \\
\hline Total & 120 & 100.0 \\
\hline
\end{tabular}

Table 10 illustrates the investors' capacity to bear risk while investing. It is revealed from the table that most of the investors took a moderate risk (33.3\%) and low risk (32.5\%).Only 6.7\% were not willing to take any risk and $27.5 \%$ of the respondents showed their willingness to take high risk while investing.

\subsection{Personality Traits}

Table II. Reliability Statistics of Personality Traits

\begin{tabular}{lll}
\hline Personality Traits & Cronbach's Alpha & N of Items \\
\hline Extraversion & .845 & 3 \\
\hline Agreeableness & .783 & 3 \\
\hline Conscientiousness & .731 & 3 \\
\hline Neuroticism & .866 & 3 \\
\hline Openness & .823 & 3 \\
\hline
\end{tabular}

Table II depicts that Cronbach's Alpha for all the items is greater than 0.7 indicating that items have a higher internal consistency in responses. Hence the scale is acceptable to conduct the study.

Table I2. Personality Traits

\begin{tabular}{ll}
\hline Personality Traits & Mean \\
\hline Friendly & $4.2 \mathrm{I}$ \\
\hline Confident & $3.7 \mathrm{I}$ \\
\hline Active & 3.58 \\
\hline Extraversion & 3.83 \\
\hline Trusting & 3.34 \\
\hline Straightforward & 3.69 \\
\hline Self-sacrifice & 3.26 \\
\hline Agreeableness & 3.43 \\
\hline Efficient & 3.74 \\
\hline Organized & 3.68 \\
\hline Achievement striving & $3.5 \mathrm{I}$ \\
\hline
\end{tabular}




\begin{tabular}{ll}
\hline Conscientiousness & 3.64 \\
\hline Anxious & 3.02 \\
\hline Self-conscious & 3.08 \\
\hline Tensed & 3.03 \\
\hline Neuroticism & 3.05 \\
\hline Imaginative & 3.42 \\
\hline Insightful & 3.42 \\
\hline Curious & 3.60 \\
\hline Openness & 3.48 \\
\hline $\mathrm{N}=\mathrm{I} 20$ & \\
\hline
\end{tabular}

Table I2 shows the respondents' personality. Respondents were asked to rate themselves on a five-point scale showing their agreement to whether they have the above-said personality traits in them or not. The mean score of the results indicated that on average respondents agreed that they were friendly (4.2I) and confident (3.7I) but were neutral on being active(3.58). So, overall, they agreed they had a small amount of extraversion trait (3.83) in them indicating that the respondents are sociable and had positive emotions in them. The mean score of trusting was 3.34 , straightforwardness was 3.69, and self-sacrifice was 3.26 indicating that the respondents had a neutral opinion regarding them being agreeable (3.43). The mean score of being efficient was 3.74, organized was 3.68, and achievement striving was 3.5I, indicating that respondents have agreed to a certain extent they had conscientiousness trait in them. This means they were self-disciplined and take planned decisions rather than spontaneous ones. The mean score of being anxious was 3.02, self- conscious was 3.08, and tensed was 3.03, which again is a neutral result, and we can say that the respondents do not consider themselves having the neurotic trait. The mean score of being imaginative was 3.42, insightful was 3.42, and curious was 3.60 , indicating that investors are not much open to new experiences(3.48) which, means they have a lower tendency to go out and check new opportunities of investments.

\subsection{Chi-Square Analysis- Risk Bearing Capacity and Demographic Characteristics}

The Chi-square test was done to find whether the risk-bearing capacity of investors is dependent on their demographic characteristics.

Table 13. Risk bearing capacity and age

\begin{tabular}{|c|c|c|c|c|c|c|}
\hline \multirow[t]{2}{*}{ Age } & \multicolumn{4}{|c|}{ Risk bearing capacity } & \multirow[t]{2}{*}{ Total } & \multirow[t]{2}{*}{ Pearson Chi-Square } \\
\hline & $\begin{array}{l}\text { No } \\
\text { risk }\end{array}$ & $\begin{array}{l}\text { Low } \\
\text { risk }\end{array}$ & $\begin{array}{l}\text { Moderate } \\
\text { risk }\end{array}$ & $\begin{array}{l}\text { High } \\
\text { Risk }\end{array}$ & & \\
\hline Less than 25 & $\mathrm{I}$ & 6 & 5 & 0 & 12 & \multirow[t]{2}{*}{ Value $=19.695^{\mathrm{a}}$} \\
\hline $26-30$ & 2 & II & 7 & 6 & 26 & \\
\hline $3 I-40$ & 2 & 7 & 16 & I5 & 40 & \multirow[t]{2}{*}{$\mathrm{df}=\mathrm{I5}$} \\
\hline $4 \mathrm{I}-50$ & 0 & 5 & 7 & 7 & I9 & \\
\hline $5 \mathrm{I}-60$ & 2 & 7 & 2 & 5 & 16 & \multirow{3}{*}{$\begin{array}{l}\text { Asymp. Sig. (2-sided) } \\
=.184\end{array}$} \\
\hline Above 6I & $\mathrm{I}$ & 3 & 3 & 0 & 7 & \\
\hline Total & 8 & 39 & 40 & 33 & $\mathrm{I} 20$ & \\
\hline
\end{tabular}

Table 13 reveals that most of the high-risk and moderate-risk takers are in the age group 3I-40. All other categories exhibit low risk-taking capacity. Analysis of the chi-square test reveals p-value (.I84) is not significant at a 5\% significance level. Therefore, it can be inferred that a person's risk-bearing capacity is not dependent on their age.

Table I4. Risk bearing capacity and gender

\begin{tabular}{lllllll}
\hline Gender & \multicolumn{4}{c}{ Risk bearing capacity } & Total & Pearson chi-square \\
\cline { 2 - 6 } & No risk & Low risk & $\begin{array}{l}\text { Moderate } \\
\text { risk }\end{array}$ & $\begin{array}{l}\text { High } \\
\text { Risk }\end{array}$ & & \\
\hline Female & 5 & 23 & I9 & 7 & 54 & Value $=$ I I.7I3a \\
\hline Male & 3 & I6 & 2I & 26 & 66 & df $=3$ \\
\hline Total & 8 & 39 & 40 & 33 & I20 & Asymp. Sig. (2-sided) $=.008$ \\
\hline
\end{tabular}


Table I4 shows that more inclination to take moderate and high-risk are found in male investors, whereas female investors tend to prefer low and moderate risk. Further analysis of the chi-square results indicates that investors' risk-bearing capacity is dependent on their gender as the findings show a p-value of .008 which is significant at a $5 \%$ level of significance.

Table I5. Risk bearing capacity and marital status

\begin{tabular}{lllllll}
\hline \multirow{2}{*}{$\begin{array}{l}\text { Marital } \\
\text { status }\end{array}$} & \multicolumn{4}{c}{ Risk bearing capacity } & Total & Pearson chi-square \\
\cline { 2 - 6 } & $\begin{array}{l}\text { No } \\
\text { risk }\end{array}$ & $\begin{array}{c}\text { Low } \\
\text { risk }\end{array}$ & Moderate risk & $\begin{array}{c}\text { High } \\
\text { Risk }\end{array}$ & \\
\hline Single & I & I3 & I2 & 7 & 33 & \\
\hline Married & 7 & 25 & 27 & 25 & 84 & Value $=5.795 a$ \\
\hline Divorced & 0 & I & 0 & I & 2 & df $=9$ \\
\hline Widowed & 0 & 0 & I & 0 & I & $\begin{array}{l}\text { Asymp. Sig. (2-sided) }= \\
.760\end{array}$ \\
\hline Total & 8 & 39 & 40 & 33 & I20 & \\
\hline
\end{tabular}

Table I5 shows the relationship between respondents' marital status and their capacity to bear the risk. It can be seen that married investors tend to take all levels of risk, and other categories take a minimal risk. It can be interpreted that risk-bearing capacity is not dependent on the marital status of the investor at a 5\% significance level with a p-value of .760.

Table I6. Risk bearing capacity and Educational Qualification

\begin{tabular}{|c|c|c|c|c|c|c|}
\hline \multirow{2}{*}{$\begin{array}{l}\text { Educational } \\
\text { Qualification }\end{array}$} & \multicolumn{4}{|c|}{ Risk Bearing Capacity } & \multirow[t]{2}{*}{ Total } & \multirow[t]{2}{*}{ Pearson Chi-Square } \\
\hline & $\begin{array}{l}\text { No- } \\
\text { Risk }\end{array}$ & $\begin{array}{l}\text { Low } \\
\text { Risk }\end{array}$ & $\begin{array}{c}\text { Moderate } \\
\text { Risk }\end{array}$ & $\begin{array}{l}\text { High } \\
\text { Risk }\end{array}$ & & \\
\hline High School & 0 & 3 & 0 & 0 & 3 & \multirow[t]{2}{*}{ Value20.925 } \\
\hline Senior Secondary & $\mathrm{I}$ & 2 & 3 & 4 & I0 & \\
\hline Graduation & 6 & I8 & I8 & 8 & 50 & \multirow[t]{2}{*}{$\mathrm{df}=\mathrm{I} 2$} \\
\hline Post-Graduation & $\mathrm{I}$ & I5 & 16 & $2 \mathrm{I}$ & 53 & \\
\hline Others & 0 & $\mathrm{I}$ & 3 & 0 & 4 & \multirow{2}{*}{$\begin{array}{l}\text { Asymp. Sig. (2- } \\
\text { sided) }=.05 \mathrm{I}\end{array}$} \\
\hline Total & 8 & 39 & 40 & 33 & $\mathrm{I} 20$ & \\
\hline
\end{tabular}

Table I6 displays the investors' capacity to bear risk based on their educational level. The results show that investors who are post-graduates take high risk compared to other categories. Others prefer low and moderate risk. It can be seen that at a 5\% significance level with a p-value of .05I, the investors' risk-bearing capacity is not dependent on their educational qualification.

Table I7. Risk bearing capacity and Occupation

\begin{tabular}{|c|c|c|c|c|c|c|}
\hline \multirow[t]{2}{*}{ Occupation } & \multicolumn{4}{|c|}{ Risk Bearing Capacity } & \multirow[t]{2}{*}{ Total } & \multirow[t]{2}{*}{ Pearson Chi-Square } \\
\hline & $\begin{array}{l}\text { No- } \\
\text { Risk }\end{array}$ & $\begin{array}{l}\text { Low } \\
\text { Risk }\end{array}$ & $\begin{array}{c}\text { Moderate } \\
\text { Risk }\end{array}$ & $\begin{array}{l}\text { High } \\
\text { Risk }\end{array}$ & & \\
\hline Salaried & 2 & I4 & 20 & 12 & 48 & \multirow[t]{2}{*}{ Value $=34.339^{a}$} \\
\hline Self Employed & 2 & 7 & 4 & 3 & 16 & \\
\hline Business & 0 & $\mathrm{I}$ & 4 & 12 & 17 & \multirow[t]{2}{*}{$\mathrm{df}=\mathrm{I} 5$} \\
\hline Professional & I & 9 & 9 & 6 & 25 & \\
\hline Retired & 2 & 5 & 3 & 0 & 10 & \multirow{2}{*}{$\begin{array}{l}\text { Asymp. Sig. (2-sided) } \\
=.003\end{array}$} \\
\hline Other & $\mathrm{I}$ & 3 & 0 & 0 & 4 & \\
\hline Total & 8 & 39 & 40 & 33 & 120 & \\
\hline
\end{tabular}

The risk-bearing capacity of the participants depending upon their occupation is displayed in table I7. It can be seen that respondents who were salaried or business-oriented take high risk, whereas those who were self-employed, professional, retired, and others take only moderate and low risk. The analysis indicated that an individual investor's risk-bearing capacity is significantly dependent on their occupation with a p-value of .003. 
Table I8. Risk bearing capacity and Monthly Income

\begin{tabular}{|c|c|c|c|c|c|c|}
\hline \multirow[t]{2}{*}{ Monthly Income } & \multicolumn{4}{|c|}{ Risk Bearing Capacity } & \multirow[t]{2}{*}{ Total } & \multirow[t]{2}{*}{ Pearson Chi-Square } \\
\hline & $\begin{array}{l}\text { No- } \\
\text { Risk }\end{array}$ & $\begin{array}{l}\text { Low } \\
\text { Risk }\end{array}$ & $\begin{array}{c}\text { Moderate } \\
\text { Risk }\end{array}$ & $\begin{array}{l}\text { High } \\
\text { Risk }\end{array}$ & & \\
\hline Up To 25,000 & 6 & $\mathrm{I} 4$ & 7 & 0 & 27 & \multirow[t]{2}{*}{ Value $=41.342^{a}$} \\
\hline $25,00 \mathrm{I}-50,000$ & $\mathrm{I}$ & 17 & 18 & 9 & 45 & \\
\hline $50,001-75,000$ & $\mathrm{I}$ & 6 & 9 & II & 27 & \multirow[t]{2}{*}{$\mathrm{df}=\mathrm{I} 2$} \\
\hline $75,001-1,00,000$ & 0 & $\mathrm{I}$ & 5 & I0 & 16 & \\
\hline Above I00,00I & 0 & $\mathrm{I}$ & $\mathrm{I}$ & 3 & 5 & \multirow{2}{*}{$\begin{array}{l}\text { Asymp. Sig. } \\
\text { sided })=.000\end{array}$} \\
\hline Total & 8 & 39 & 40 & 33 & 120 & \\
\hline
\end{tabular}

Cross tabulation of respondents' risk-bearing capacity and their monthly income is displayed in table I8. It can be seen that respondents who have a salary above 50000 tend to take high risk. Those who have an income of 2500I -50000 take moderate risk, and those who have income below 25000 take a low risk. The analysis indicated an individual investor's risk-bearing capacity is significantly dependent on their monthly income with a p-value of .000 .

\subsection{Chi-Square Analysis- Personality Traits and Risk-Bearing Capacity}

Table 19. Chi-Square Test - Personality traits and Risk-bearing capacity

\begin{tabular}{llll}
\hline \multirow{2}{*}{ Personality Traits } & \multicolumn{3}{c}{ Risk bearing capacity } \\
\cline { 2 - 4 } & Pearson Chi-Square & $\mathrm{df}$ & Asymp. Sig. (2-sided) \\
\hline Friendly & 73.842 & 9 & .000 \\
\hline Confident & 85.838 & $\mathrm{I} 2$ & .000 \\
\hline Active & 91.907 & $\mathrm{I} 2$ & .000 \\
\hline Extraversion & $\mathrm{I} 40.090$ & 30 & .000 \\
\hline Trusting & $\mathrm{I} 38.332$ & $\mathrm{I} 2$ & .000 \\
\hline Straightforward & 66.003 & $\mathrm{I} 2$ & .000 \\
\hline Self-sacrifice & $\mathrm{I} 53.569$ & $\mathrm{I} 2$ & .000 \\
\hline Agreeableness & $\mathrm{I} 77.546$ & 36 & .000 \\
\hline Efficient & 79.678 & $\mathrm{I} 2$ & .000 \\
\hline Organized & 52.884 & $\mathrm{I} 2$ & .000 \\
\hline Achievement striving & $\mathrm{I} 85.263$ & $\mathrm{I} 2$ & .000 \\
\hline Conscientiousness & $\mathrm{I} 44.637$ & 33 & .000 \\
\hline Anxious & $90.86 \mathrm{I}$ & $\mathrm{I} 2$ & .000 \\
\hline Self-Conscious & 64.172 & $\mathrm{I} 2$ & .000 \\
\hline Tensed & $\mathrm{I} 08.837$ & $\mathrm{I} 2$ & .000 \\
\hline Neuroticism & $\mathrm{I} 52.867$ & 36 & .000 \\
\hline Imaginative & 23.479 & $\mathrm{I} 2$ & .024 \\
\hline Insightful & $22.10 \mathrm{I}$ & $\mathrm{I} 2$ & .036 \\
\hline Curious & $24.20 \mathrm{I}$ & $\mathrm{I} 2$ & .019 \\
\hline Openness & $48.65 \mathrm{I}$ & 36 & .078 \\
\hline
\end{tabular}

Table 19 shows the results of the chi-square analysis of personality traits and risk-bearing capacity. The results indicate that an investor's capacity to bear risk is significantly dependent on extraversion, agreeableness, conscientiousness, and neuroticism. It can be further noted that the risk-bearing capacity of the respondents was not dependent on openness to experience. It can, therefore, be deduced that the capacity to bear risk is related to investors' personality.

\subsection{Nonparametric Correlations - Personality Traits and Risk Bearing Capacity}

Table 20. Nonparametric Correlations - Personality traits and Risk bearing capacity

\begin{tabular}{llll}
\hline Personality Traits & \multicolumn{3}{c}{ Risk bearing capacity } \\
\cline { 2 - 4 } & Correlation Coefficient & Sig. (2-tailed) & $\mathrm{N}$ \\
\hline Friendly & $.675^{\text {tw }}$ & .000 & $\mathrm{I} 20$ \\
\hline Confident & $.717^{\text {twa }}$ & .000 & $\mathrm{I} 20$ \\
\hline
\end{tabular}




\begin{tabular}{|c|c|c|c|}
\hline Active & $.716^{\ldots}$ & .000 & 120 \\
\hline Extraversion & $.789^{\text {wht }}$ & .000 & 120 \\
\hline Trusting & $.83 I^{\text {wa }}$ & .000 & 120 \\
\hline Straightforward & $.54 \mathrm{I}^{+4}$ & .000 & 120 \\
\hline Self-sacrifice & $.862^{n+m}$ & .000 & $\mathrm{I} 20$ \\
\hline Agreeableness & $.885^{\text {tha }}$ & .000 & $\mathrm{I} 20$ \\
\hline Efficient & $.612^{m+n}$ & .000 & 120 \\
\hline Organized & $.50 \mathrm{I}^{\text {th }}$ & .000 & $\mathrm{I} 20$ \\
\hline Achievement striving & $.822^{\text {kn }}$ & .000 & I20 \\
\hline Conscientiousness & $.820^{* 4 *}$ & .000 & I20 \\
\hline Anxious & $-.673^{\text {皮 }}$ & .000 & 120 \\
\hline Self-Conscious & $-.496^{\text {math }}$ & .000 & 120 \\
\hline Tensed & $-.68 \mathrm{I}^{\text {sta }}$ & .000 & $\mathrm{I} 20$ \\
\hline Neuroticism & $-.685^{\text {than }}$ & .000 & 120 \\
\hline Imaginative & .120 & .193 & 120 \\
\hline Insightful & .170 & .063 & 120 \\
\hline Curious & $.233^{*}$ & .010 & 120 \\
\hline Openness & $.18 \mathrm{I}^{*}$ & .048 & 120 \\
\hline \multicolumn{4}{|c|}{ significant at the $0.0 \mathrm{I}$ level } \\
\hline . significant at the 0.0 & & & \\
\hline
\end{tabular}

Table 20 shows the correlation results of personality traits and risk-bearing capacity. The results indicate that the risk-bearing capacity of the investors was positively correlated (.675) with friendly trait and is significant ( $\mathrm{p}$-value $=.000$, at I\% level of significance). The confident trait was positively correlated (.7I7) with the risk-bearing capacity of the respondent and is significant ( $\mathrm{p}$-value $=.000$, at $\mathrm{I} \%$ level of significance). The active trait was positively correlated (.7I6) with risk-bearing capacity and is significant ( $\mathrm{p}$-value $=.000$, at $\mathrm{I} \%$ level of significance). This implies that the risk-bearing capacity of the individual investor is positively correlated (.789) with extraversion trait and is significant which means those who are high in extraversion take more risk and those with low scores in extraversion take less risk.

The results show that the risk-bearing capacity of the investors was positively correlated (.83I) with the trusting trait and is significant ( $\mathrm{p}$-value $=.000$, at $\mathrm{I} \%$ level of significance). The straightforward trait was positively correlated (.54I) with the risk-bearing capacity of the respondent and is significant ( $\mathrm{p}$-value $=.000$, at $1 \%$ level of significance). The selfsacrifice trait was positively correlated (.862) with risk-bearing capacity and is significant ( $\mathrm{p}$-value $=.000$, at $\mathrm{I} \%$ level of significance). This denotes that the risk-bearing capacity of the individual investor is positively correlated (.885) with agreeableness trait and is significant which means those who are low in agreeableness take less risk and those with high agreeableness trait prefer more risk.

We can observe from the table that the trait of efficiency is positively correlated (.6I2) with their risk-bearing capacity. Risk-bearing capacity is positively correlated with organized (.50I) and achievement striving (.822) trait also. Hence it can be stated that risk-bearing capacity is significantly and positively related to conscientiousness $(.820)$.

Further from the table when the next set of personality traits were analyzed, it was observed that anxiousness (-.673), selfconsciousness (-.496), and tensed trait (-.68I) are highly negatively correlated with the risk-bearing capacity of the investor. Therefore, it means that risk-bearing capacity is highly negatively correlated with neuroticism (-.685), which denotes that those with low neuroticism take high risk and those with high neuroticism take a low risk.

The last set of traits that were examined was openness to experience. It was observed that traits of imagination(.I20), insightfulness (.I70), and curiousness (.233) had a very minimal correlation with respondents' riskbearing capacity and this further pointed out that openness to experience and risk-bearing capacity have a very low correlation (.I8I).

To sum up, an investors' risk-bearing capacity and their personality are related.

\section{Findings}

\section{I Demographic Characteristics}

The majority of the participants in the study were from the 3I-40-year-old age group (33.3\%). Gender wise distribution showed that $55 \%$ of them were male, and $45 \%$ were female. The majority of the people surveyed were married $(70 \%)$. Most of the respondents were graduates (4I.7\%) and post-graduates (44.2\%). Out of the surveyed respondents, $40 \%$ were salaried, $20.8 \%$ were professionals, I4.2\% were businessmen, I3.3\% were self-employed, $8.3 \%$ were retired, and $3.3 \%$ had other occupations. The most prominent income group was Rs. 2500 I to 50000 which had $37.5 \%$ investors followed by 22.5\% investors in both Rs. 5000 I - Rs. 75000 and less than Rs. 25000 categories. 


\subsection{Investment Pattern}

- The outcomes of the survey indicated that the majority of investors made investments up to Rs. 2500 in a month (25.8\%).

- The majority of the investors made investments once in a month $(53.3 \%)$.

- The main objectives for which the respondents made investments were for obtaining higher returns, tax benefits, financial independence, and retirement purpose.

- The most preferred time-period for making investments were I-3 years

- Prominent avenues in which the respondents currently made their investments were bank deposits, insurance, provident fund, mutual funds, and gold and silver.

- The results of the most preferred avenues of investment showed that the most desired product was bank deposit, followed by insurance and gold and silver.

- Sources from which the respondents gathered information were self-analysis, friends, and family.

- Most of the investors had an investment experience of 2-5 years.

\subsection{Risk-Bearing Capacity}

The majority of the respondents showed their willingness to take a moderate risk (33.3\%) and low risk (32.5\%).

\subsection{Personality Traits}

The analysis of the results showed that a major share of the respondents showed extraversion and conscientiousness trait in them.

\subsection{Demographic Characteristics and Risk-Bearing Capacity}

The Chi-square test was done to find whether investors' capacity to bear risk is dependent on their demographic characteristics. Dependence was observed in the case of gender, occupation, and monthly income of investors. It was also further noted that risk-bearing capacity is not dependent on age, marital status, and educational qualification. Hence the hypothesis $\left(\mathrm{H}_{\mathrm{I}}\right)$ that the risk-bearing capacity of the investor is dependent on demographic characteristics is partially correct in the case of gender, occupation, and monthly income. These results appear to support the observations reported by Thanki and Baser (2019), who remarked that gender, income, and occupation have a prominent role in determining the financial risk tolerance of investors. Similar patterns were obtained by Grable (2000).

\subsection{Personality Traits and Risk-Bearing Capacity}

The results of the chi-square test indicate that the investors' capacity to bear risk depends heavily on extraversion, agreeableness, conscientiousness, and neuroticism. It can be further noted that the capacity to bear risk is independent of openness to experience. Hence, we can interpret that the investor's risk-bearing capacity is related to their personality.

Results of the correlation analysis show that risk-bearing capacity is positively correlated with extraversion, agreeableness, and conscientiousness. This indicates that those who have more scores in these traits are inclined to take high risk. Risk-bearing capacity is negatively correlated with neuroticism. This indicates that a person with greater scores in neuroticism prefers to take fewer risks. Hence, it can be said that an investor's capacity to bear risk is driven by their personality traits.

Therefore, the hypothesis $\left(\mathrm{H}_{2}\right)$ that the risk-bearing capacity of the investor is dependent on their personality trait is accepted. Similar results were reported by Gupta and Agarwal (2018).

\section{Conclusion}

In the present scenario, investors are offered with an abundant supply of investment products, and choosing an appropriate opportunity has become very difficult for them. Investors have to decide how much to invest, where to invest, and when to invest. These decisions are usually driven by numerous aspects, and risk involved in investing is the prominent one among them.

This study was carried out to ascertain the impact of demographic factors and personality traits on the risk-bearing capacity of the investors. The results of the analysis showed that the investors' capacity to bear risk was highly dependent on demographic factors like gender, occupation, and monthly income. It was also identified that the personality traits of investors have a strong relationship with their risk-bearing capacity. Those who were agreeable, extravert, and conscientiousness were found to take more risk than others. Those who exhibited high neuroticism were found to take a very minimal risk.

This research work points out how personality and demographic factors of an investor have an impact on their capacity to bear the risk and as such on investment decisions. Findings of Dhiman and Raheja (2018) and Thomas and Rajendran (2012) also support these inter-linkages that exist among demographic traits, personality traits, and investment decisions. Hence, it can be said that having a proper understanding of these factors can help investors to understand their current capacity to bear the risk and take appropriate decisions while investing. It will be beneficial for financial institutions in gaining a better understanding of which product should be offered to which type of investors. It would be useful for financial advisors in providing proper guidance about investment avenues to their clients considering their perso nalities. 
References

Alwahaibi, S. S. O. (2019). Is Demographic Information Influence Risk Tolerance/Aversion in Investment Decision? Evidences from Literature Review. International Joumal of Academic Research in Accounting, Finance and Management Sciences, (I), I I I-I22. https://doi.org/I0.6007/IJARAFMS/v9-iI/5825

Asano, S., \& Tachibanaki, T. (1994). Relative risk aversion once more: An analysis of Japanese households' financial asset holding pattern. Financial Engineering and the Japanese Markets, I(2), I37-I54. https://doi.org/I0.1007/bf02425I94

Croson, R., \& Gneezy, U. (2009). Gender Differences in Preferences. Journal of Economic Literature, 472), 448-474. https://doi.org/I0.1257/jel.47.2.448

Dhiman, B., \& Raheja, S. (2018). Do Personality Traits and Emotional Intelligence of Investors Determine Their Risk Tolerance? Management and Labour Studies, 43(I\&2), 88-99. https://doi.org/I0.I 177/0258042XI7745I84

Dickason, Z., \& Ferreira, S. (2018). Establishing a link between Risk Tolerance, Investor Personality and Behavioural Finance in South Africa. Cogent Economics \& Finance, 6, I-I3. https://doi.org/I0.1080/23322039.2018.1519898

Durand, R. B., Newby, R., Peggs, L., \& Siekierka, M. (2013). Personality. Journal of Behavioral Finance, I4(2), I I6-I33. https://doi.org/I0.1080/I5427560.2013.791294

Durand, R., Newby, R., Tant, K., \& Trepongkaruna, S. (2013). Overconfidence, Overreaction and Personality. Review of Behavioral Finance, 5(2), I04-I33. https://doi.org/I0.I I08/RBF-07-20I2-00I I

Dwyer, P. D., Gilkeson, J. H., \& List, J. A. (2002). Gender differences in revealed risk taking: Evidence from mutual fund investors. Economics Letters, 76(2), I5I-I58. https://doi.org/I0.1016/s0I65-1765(02)00045-9

Gondaliya, V., \& Dhinaiya, G. (2016). Assessing Financial Risk Tolerance: Do Demographic, Socioeconomic and Attitudinal factors work? International Journal of Marketing \& Financial Management, 4(5), 32-38. Retrieved from

http://bvpinst.edu.in/download/Publication/II.\%20Assessing\%20Financial\%20Risk\%20Tolerance\%20Do\% 20Demographic,\%20Socioeconomic\%20and\%20Attitudinal\%20Factors\%20Work\%20by\%20Vijay\%20G,\%2 OGovind\%20D.pdf

Grable, J. E. (2000). Financial risk tolerance and additional factors that affect risk taking in everyday money matters. Journal of Business and Psychology, I4(4), 625-630. https://doi.org/I0.I023/a:I0229943I 4982

Gupta, C., \& Agarwal, K. (2018). Portfolio Investor Personality Traits and Portfolio Investment Decisions: An empirical analysis. International Joumal of Commerce and Management Research, 4(5), I2-I8. Retrieved from http://www.managejournal.com/download/692/4-4-32-II9.pdf

Holton, G. A. (2004). Defining Risk. Financial Analysts Journal, 6066), 19-25. https://doi.org/I0.2469/faj.v60.n6.2669

Isidore, R. R., \& Christie, P. (2017). Review of the influence of Investor Personality (The Big 5 Model) on Investor Behavior. International Journal of Research in Finance and Marketing, 7(7), 9-18. Retrieved from http://euroasiapub.org/wp-content/uploads/2017/08/2FMJuly-5203P-I.pdf

Mayfield, C., Perdue, G., \& Wooten, K. (2008). Investment management and personality type. Financial Services Review, I7, 2I9-236. Retrieved from http:/ / citeseerx.ist.psu.edu/viewdoc/download?doi=I0.I.I.320.6394\&rep=repI\&type $=$ pdf

Outreville, J. F. (2015). The relationship between Relative Risk Aversion and the level of education: A survey and implications for the demand for life insurance. Journal of Economic Surveys, 29(I), 97-III. https://doi.org/IO.I III/joes.I2050

Thanki, H., \& Baser, N. (2019). Interactive impact of Demographic Variables and Personality Type on Risk Tolerance. Emerging Economy Studies, 5(I), 42-54. https://doi.org/I0.I I77/2394901519825924

Thomas, T. C., \& Rajendran, G. (2012). BB\&K Five-way Model and Investment Behavior of Individual Investors: Evidence from India. International Journal of Economics and Management, 6(I), II5-I27. Retrieved from http://www.ijem.upm.edu.my/vol6noI/bab07.pdf 
Appendix

\section{Questionnaire}

Name

Email address

\section{A. Demographic Profile}
I. Age $\square$ Up to 25
$\square$ 26-30
$3 \mathrm{I}-40$
4I-50
5I-60
$\square 6 \mathrm{I}$ and Above

2. Gender $\square$ Female $\square$ Male

3. Marital Status $\square$ Single

$\square$ Married $\square$ Divorced $\square$ Widowed

4. Educational Qualification $\square$ High School $\quad \square$ Senior Secondary $\quad \square$ Graduation

$\square$ Post-Graduation $\square$ Others

5. Occupation $\square$ Salaried $\square$ Self Employed $\square$ Business

$\square$ Professional $\square$ Retired $\square$ Other

6. Monthly Income $\square$ Up to Rs. 25,000 $\square$ Rs. 25,00I - Rs. 50,000 $\square$ Rs. 50,00I - Rs. 75,000

$\square$ Rs. 75,00I- Rs. I,00,000 $\square$ Above Rs. I00,00I

\section{B. Investment Pattern}

7. Investments per month $\square$ Up to Rs. 2,500

$\square$ Rs. 2,50I - Rs. 5,000

$\square$ Rs. 5,00I - ₹7,500

$\square$ Rs. 7,50I- ₹I0,000 $\square$ Above Rs. I0,00I

8 . Frequency of making investments
$\square$ Once in a month
$\square$ Once in 3 months
$\square$ Once in 6 months
$\square$ Once in a year

$\square$ Combination of all of the above

9. Investment objective (Select the reasons for making investment (Multiple selections possible))
$\square$ Higher returns
$\square$ Tax benefits
$\square$ Safety of money
$\square$ Financial independence
$\square$ Retirement purpose
$\square$ Children education and marriage
$\square$ Stable income
$\square$ Others (Please specify)

I0. Preferred time-period of investment
$\square$ 0-I year
$\square$ I-3 years
3-5 years
Above 5 years

II. Current investments (Select all those products in which you have invested your money - multiple selections)
$\square$ Bank deposit
$\square$ Postal savings
$\square$ Provident fund
$\square$ SIP (Systematic Investment plans)
$\square$ Insurance
$\square$ Gold and silver
$\square$ Real estate
$\square$ Chit funds
$\square$ Mutual funds
$\square$ Shares
$\square$ Others (Please specify)

I2. Investment preference (Please rank your investment preference. Refer to question II for the investment options) i) ii)_iii)

I3. Source of information (Select all the sources from where you gather information regarding various investment products)
$\square$ Self Analysis
$\square$ Spouse
$\square$ Family
$\square$ Friends
$\square$ Colleagues
$\square$ Financial institutions
$\square$ Financial websites
$\square$ Advertisements
$\square$ Others (Please specify) 
I4. Investment experience (How long have you been making investments?)
$\square 0$ - I year
$\square 2-5$ years
$\square 5$ - 10 years
$\square$ Above 10 years

\section{Risk Bearing Capacity}

I5. Choose from the following regarding how much risk you are willing to take while making an investment
$\square$ No risk
$\square$ Low-risk
$\square$ Moderate risk
$\square$ High risk

\section{Personality Traits}

I6. The following are a set of personality characteristics. Rate yourself on a scale of $\mathrm{I}$ to 5 to indicate your agreement to whether you have these characteristics or not. ( $\mathrm{I}=$ Strongly Disagree; $2=$ Disagree; $3=$ Neutral; $4=$ Agree; 5 = Strongly Agree)

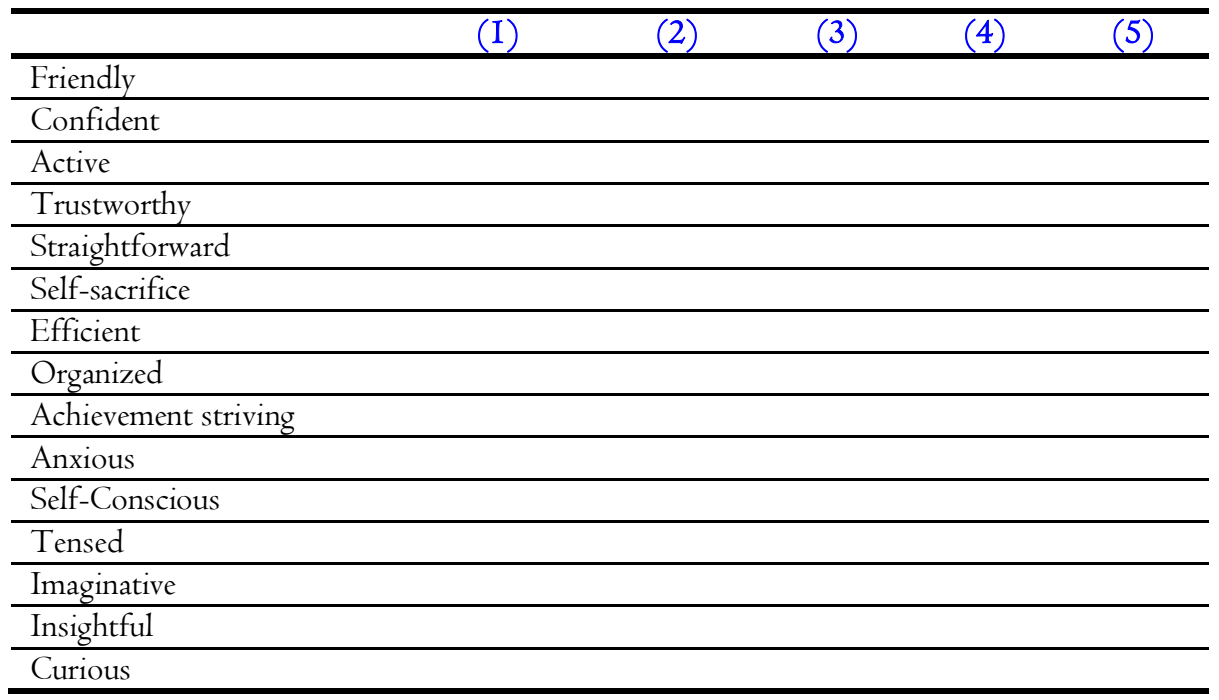

\section{Copyrights}

Copyright for this article is retained by the author(s), with first publication rights granted to the journal. This is an openaccess article distributed under the terms and conditions of the Creative Commons Attribution license (http://creativecommons.org/licenses/by/4.0/). 